\title{
A morphometric method to determine neotecto- nic activity of the Weihe basin in northwestern China
}

\author{
I Department of Geology, Peking University, Beijing 100871, China \\ 2 Department of Geography, Peking University, Beijing 10087I, China \\ 3 Centre for Resources and Environmental Stadies, Australia National University, Canberra ACT 020 ). Australia
}

\begin{abstract}
In order to study the Holocene activity in the downfaulted Weihe Basin, northwest China, the authors conducted a semi-quantitative morphotectonic analysis of the drainage density using topographic maps (1:50,000) and through field investigation. The results obtained have been supported by drill hole data, repeated geodetic surveying and an isopach map of Quaternary strata. They indicate that the Holocene tectonic activity was characterized by block-faulting of the basement on different scales against a background of southward down tilting, with differential movement of small blocks. The mechanism of block movement is shear extension of the NNE-trending Fenwei Graben System under the action of right-lateral shearing. The method, if as valid as it seems in this investigation, is useful in predicting tectonic style and geological hazard where data other than maps are lacking.
\end{abstract}

\section{Introduction}

The Weihe Basin is a part of the Fenwei Graben System located in the soutbwestern part of North China fault block. The basin is bounded by the Qinling Mts. tilt block to the south and the Ordos block to the north. Geophysical and drilling data reveal a complicated asymmetric basin, shallow in the north and deeply downfaulted in the south (Deng and You, 1985; Wang, 1983; Hou, 1991).

Faults in the basin fall into three groups striking E-W, NW and $\mathrm{NE}$ respectively, and cut the basin into many blocks of different sizes (Figure 1).

Differential movement between the blocks has been the dominant style of neotectonic movement in the basin (Han and Yi, 1982; Hou et al., 1993).

Tectonic activity induced many geological hazards. A strong earthquake ( $M=8,1556$ ) causing the heaviest casualties in the history of China occurred in Huaxian county in the southeastern part of the basin (Hou, 1985; Pan et al., 1993; Zhang et al., 1989).

In recent years geological hazards such as ground cracking, landslides and debris flows often occur at the centre of the basin or along its margin. (Wang, 1989; Hou et al., 1994). To effectively control such geological hazards it is necessary to investigate the active tectonics and relevant selting.
But it is hard to examine tectonic structures in the basin by conventional geological methods because the basin is covered by thick unconsolidated sediments.

Geophysical methods can be used to define the distribution of the basement faults and blocks. Geodetic methods can only be utilised in a very short term to identify the tectonic movement in the past few decades. These methods, however, need time and money, making it impossible to determine the total characteristics of a large area in a short time. The method of shifting of rivers (Schumm, 1986 ) is only qualitative and can not reveal all buried tectonic leatures (Su, 1991).

We have devised a method of drainage density analysis that can reveal the buried Holocene tectonic activity and remedy the defects of conventional geomorphic and instrumental measuring methods.

\section{Principle of the method}

The morphometric method of drainage density analysis is based on the following principle: In a subsiding region, especially when the intensity of subsidence is equal to or lower than that of deposition. water will flow slowly, causing the development of tributaries and the formation of a drainage network. That will result in an increase of the total length of drainage per unit area, which is the value of drainage length density. When the rate of subsidence is greater than the rate of deposition, river courses will become much wider and develop meandering. That will lead to an increase of the total area of drainage per unit area (the accumulative area of length times width of the total drainage per unit), namely the value of drainage area density. The drainage length density may be somewhat reduced because many closely spaced parallel rivers may join together to become a single wide large river.

During the early stage of an uplift region higher when the intensity of uplift was larger than that of river down-cutting, the streams and rivers would rapidly deepen and narrow their courses, and some of them would decline and even disappear. That would result in the formation of few and scattered drainage lines. In this case the drainage length density significantly decreases.

During the middle or late stage of an uplift region when the intensity of uplift was equal to or lower than that of river downcutting, a new gully network will develop on the margins of an uplifting block due to headward erosion. This would lead to the formation of a radial, dense drainage pattern with many narrow, downcutting gullies. In such a case the drainage length density may become much higher, producing a false image of tectonic subsidence. But such an interpretation can be avoided by analysing the map of drainage area density, because in this situation all the river courses in the uplifted area are very narrow and the value of drainage area density is small. 


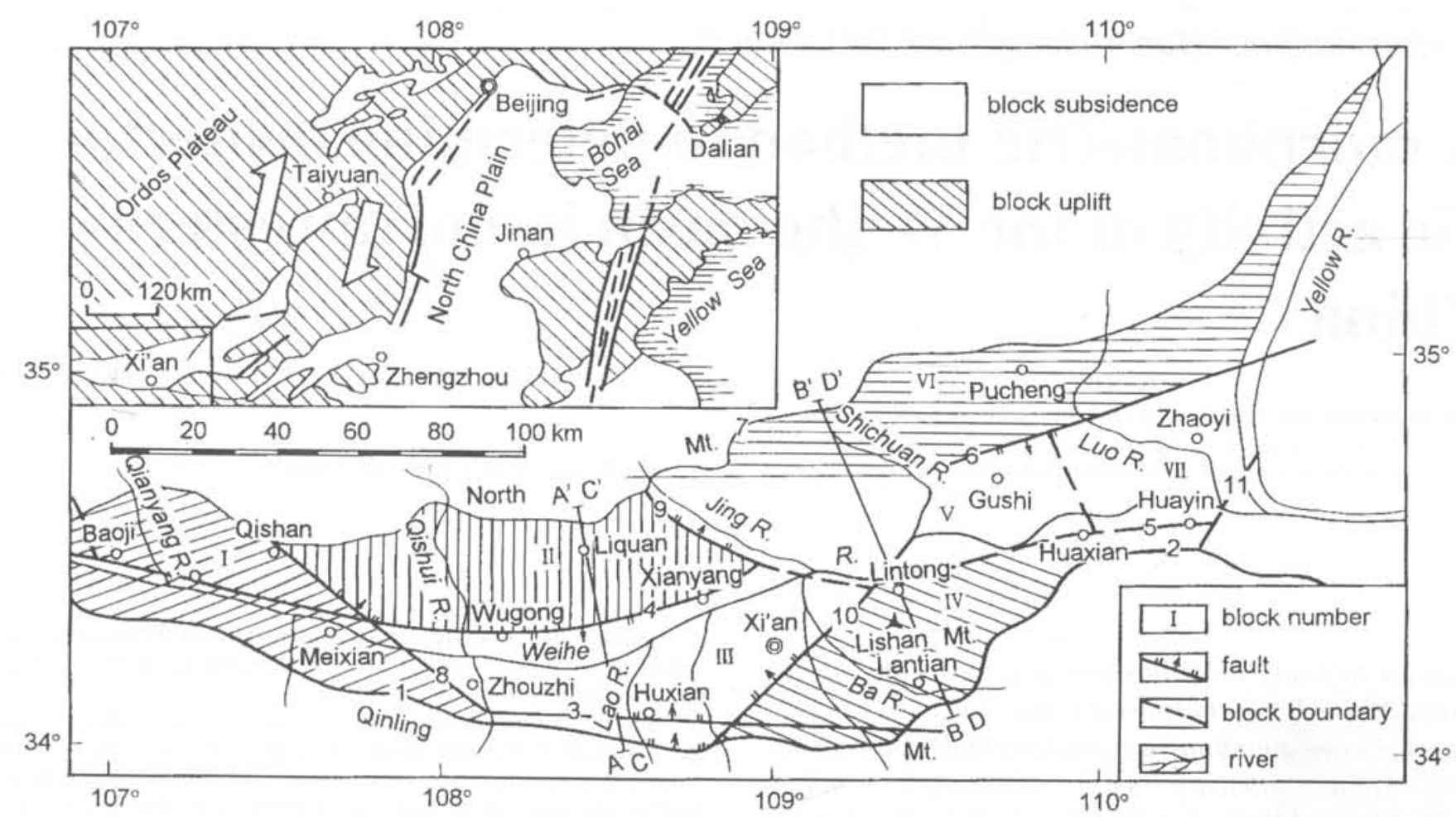

Figure 1. Tectonic location of the Weihe Basin and recognition of fault blocks in it.
I. Baoji block uplift,
II. Liquan block uplift,
III. Xi' an block subsidence,
IV. Lishan block uplift,

V. Gushi block subsidence, VI. Pucheng block uplift, VII. Zhaoyi block subsidence.

1. North Qinling piedmont fault,

4. North Weihe bank fault,

7. South piedmont fault of the North Mts.,

10. Lintong-Chang'an fault,
2. North Huashan piedmont fault,

5. South Weihe bank fault.

8. Yabo fault,

11. western margin fault of Tongguan.
3. Yuxia fault,

6. fault of southern margin of Pucheng block, 9. Jinghe fault,
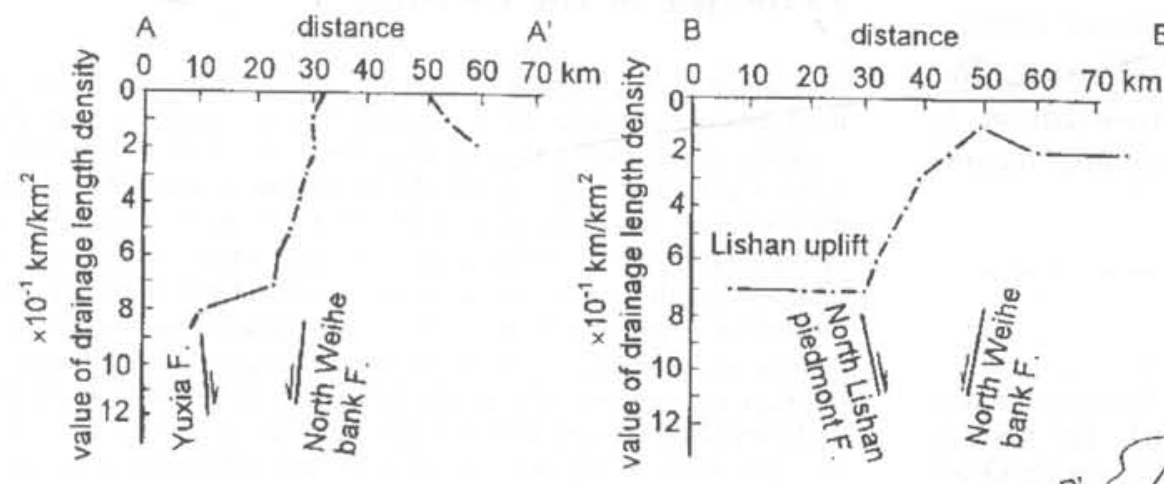

$B^{\prime}$

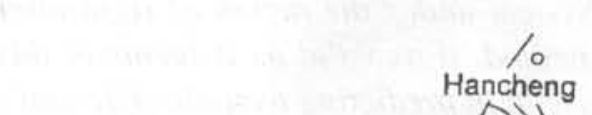




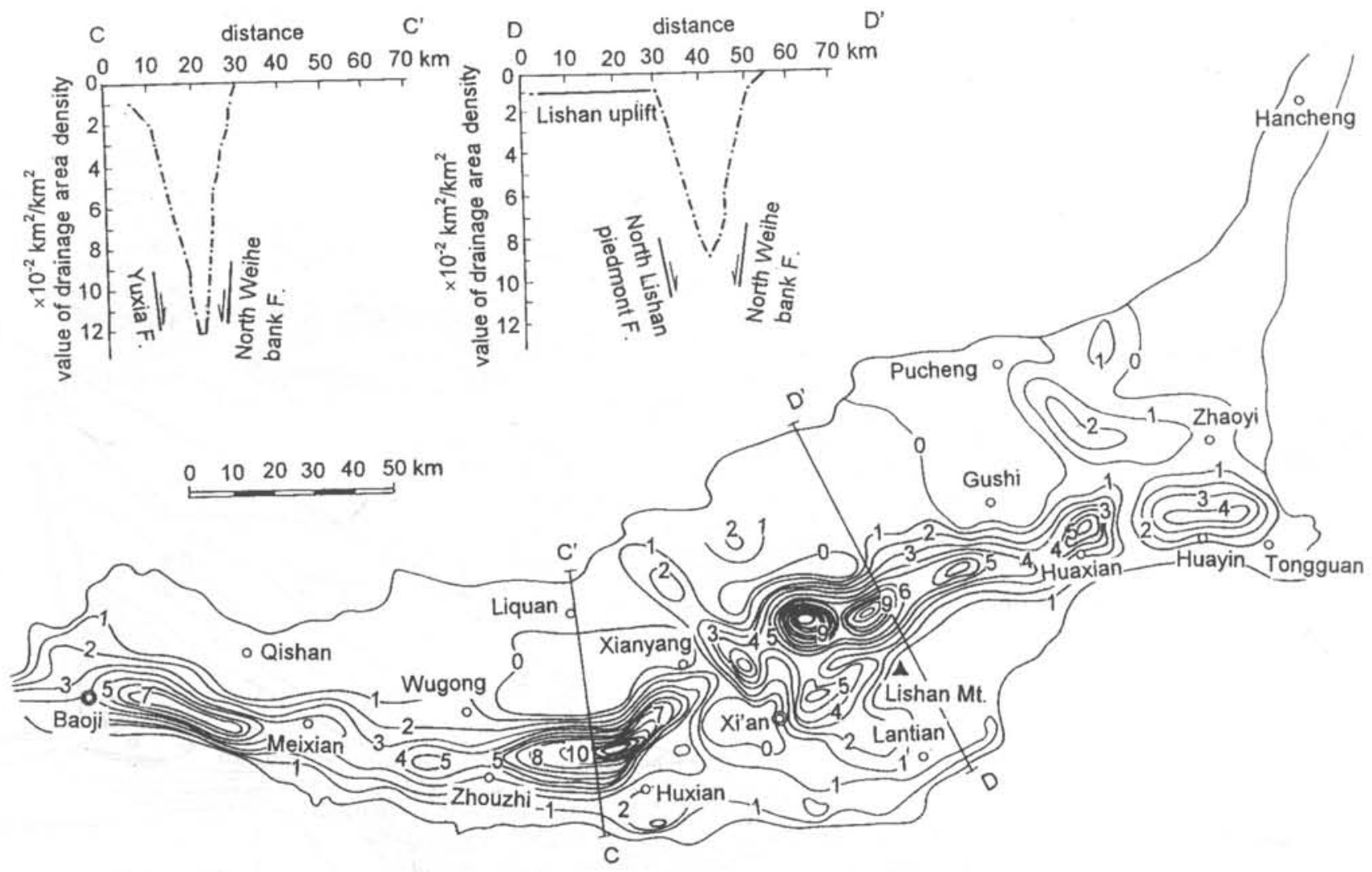

Figure 3. Isogram of drainage area density in the Weihe basin (unit: $x 10^{-2} \mathrm{~km}^{2} / \mathrm{km}^{2}$ )

So for a correct tectonic interpretation it is essential to compare the two kinds of maps.

\section{Method of drainage density analysis}

The method involves the following stages:

1. A large scale topographic map is divided into a grid of squares ( $\leq 1 \mathrm{~km}, \leq 4 \mathrm{~km}, \leq 9 \mathrm{~km}$, or $\leq 25 \mathrm{~km}$ as desired).

2 . In each square the drainage length (stream and river) is measured to get the drainage length density.

3. In each square the length times width of drainage (stream and river) is measured to get the drainage area density.

4. The point values are then plotted on small-scale maps $(1: 500,000)$, and contoured to obtain two new maps: the map of drainage length density ( Figure 2 ) and the map of drainage area density (Figure 3 ).

5. The two maps are compared to determine the geometric expression of buried Holocene tectonic activity.

6. The activities and patterns of buried structures of recent Holocene time as well as their activity intensity are identified by using these two maps in combination with geophysical, geological and geodetic data, and by field checking.

\section{Characteristics of buried structures in the Weihe Basin}

We applied the theory and method described above to the Weihe Basin Plain. Comparing the two drainage density maps (Figures 2 and 3) with the maps of neotectonics (Figure 1), Quaternary isopach map (Figure 4a) and geodetic measurements (Figure 4b), the following tectonic conclusions can be drawn:

1. The isopleths of drainage length and area densities are distributed in a narrow strip along the southern margin of the Weihe Basin, that is the northern piedmont of the Qinling Mountain and Huashan Mountain. The values of the drainage length density and area density are highest $\left(9 \times 10^{-1} \mathrm{~km} / \mathrm{km}^{2}\right.$ and $1 \times 10^{-2} \mathrm{~km}^{2} / \mathrm{km}^{2}$ respectively), which reflects strong down-faulting there.

In contrast, the isopleths of drainage length and area densities are few and scattered in the northern part of the basin, and the values of the densities are lowest $\left(1 \times 10^{-1} \mathrm{~km} / \mathrm{km}^{2}\right.$ and $1 \times 10^{-2} \mathrm{~km}^{2} / \mathrm{km}^{2}$, and even zero), which reflects uplifting in the northern part of the basin. We can therefore conclude that the basin plain has been rising in the north and subsiding in the south during the Holocene.

The Quaternary isopach map shows that the sediment is deep in the southern part and shallow in the northern part of the basin (Figure $4 a)$,

The geodetic map shows upward movement in the north of the basin and downward movement in the south (Figure 4b).

All these facts show that the basin is characterized by a blocktilting intensifying from north to south, so that the southern margin of the basin is structurally strongly active, thus causing many large earthquakes and geological hazards (Wang, 1987; Xie et al., 1991; Shentu et al., 1991; Hou et al., 1993 and 1994).

2. Recent vertical differential movements of basement blocks are reflected by the different confining zones on the drainage length density and drainage area density maps.

For example, the confining zones of low isopleth in the two uplifted blocks of the Liquan and Pucheng areas reflect posthumous uplifting there (Figures 2 and 3). However, the Lishan and Baoji uplifting blocks are only reflected on the map of drainage area density (Figure 3), with low or zero isopleths. The reason is that the streams are crowded together to make the high value of drainage 


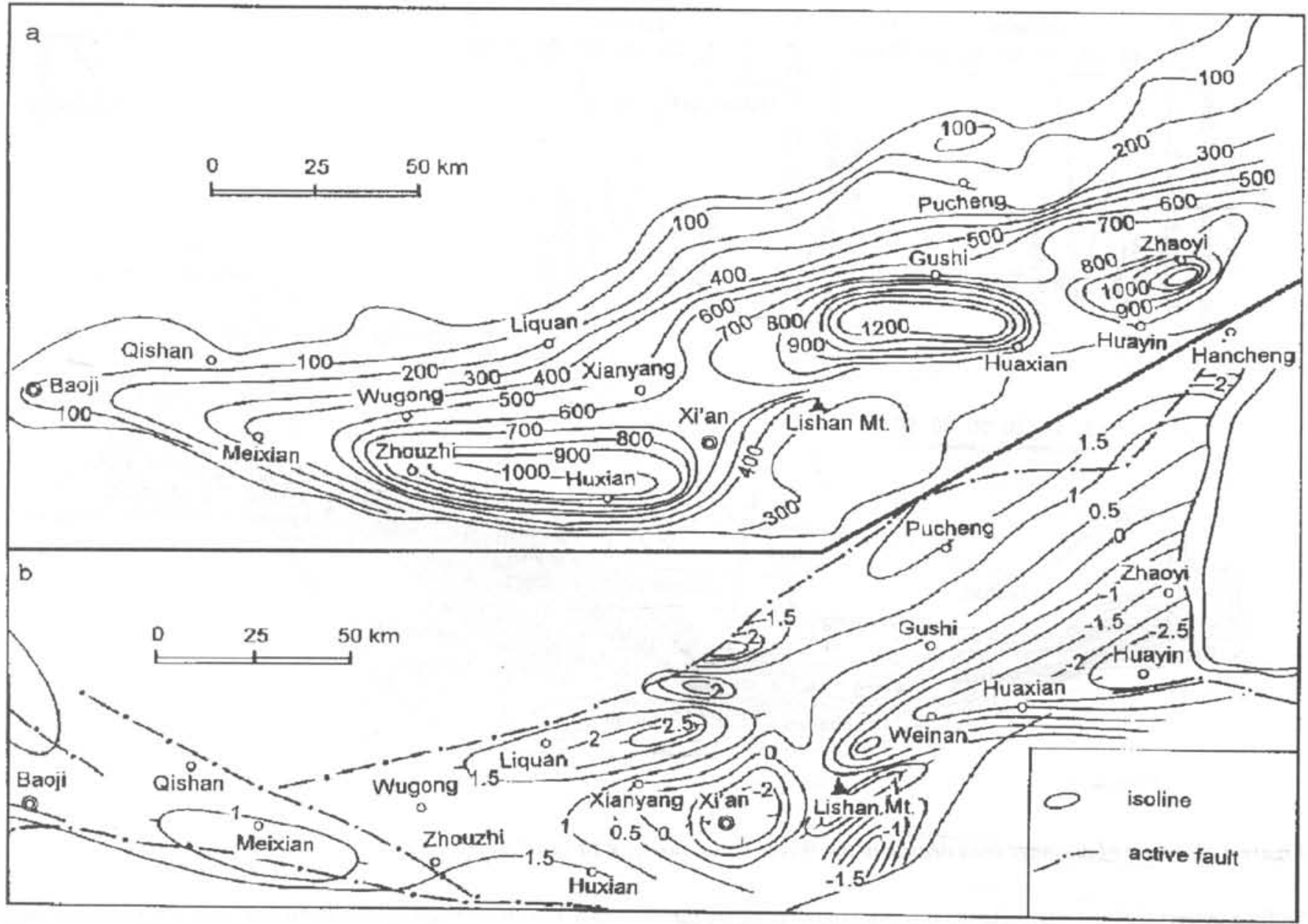

Figure 4 a: The thickness (in meters) of the Quaternary System in the Weihe Basin (after Li, 1986).

$b$ : The isolines of current crustal vertical deformation rate (in $\mathrm{mm} / \mathrm{a})(1954-1978$ ) in the Weihe Basin (after the Second Team of Crustal Deformation Survey, State Seismological Bureau of China).

length density, but the streams are narrow and cut deeply to cause the low value of drainage area density.

3. The three down-faulted blocks are well-shown on both the maps of drainage length density and drainage area density, with higher isopleth confining areas which coincide with the three subsiding centres shown on the Quaternary isopach map (Figure 4a). The significant features are that the subsidence of the western part of the Gushi downfaulted block is marked by higher isopleths of drainage densities, but the eastern part is slightly uplifted and has lower isopleths. The isopleths show that the Gushi downfaulted block is tilting, displaying a slight uplift in the east and a subsidence in the west.

4. Another example is the Xi' an downfaulted block. The values of drainage density isopleths in the northeastern part are low, reflected uplift, and the values in its southwestern part are very high, reflecting strong subsidence. The isopleths show that the $\mathrm{Xi}$ ' an block is tilting from northeast to southwest. A complication occurs in Xi'an city: the city is located in the northeastern part of the Xi'an block and so it should be uplifted, but geodetic survey suggests that it is subsiding (Figure $4 \mathrm{~b}$ ). Such a subsidence of the city is caused by excessive extraction of groundwater, not by tectonic activity.

5. The Jinghe fault trends northwest along the eastern margin of the Liquan uplift block, and is expressed as a narrow and long confining zone with higher values of drainage area density (Figure 3), and as a steep slope of drainage length density isopleths (Figure 2). The activity of the fault is not reflected on Quaternary isopach map or geodetic map.

6. Sections can be drawn across basins using the isopleths of drainage density to illustrate recent movement in a basin. Two sections have been drawn across the downfaulted Weihe Basin (Figures
2 and 3 , sections $\mathrm{A}-\mathrm{A}^{\prime}, \mathrm{B}-\mathrm{B}^{\prime}, \mathrm{C}-\mathrm{C}^{\prime}$ and $\left.\mathrm{D}-\mathrm{D}^{\prime}\right)$, and are interpreted as follows:

The sections of drainage length density isopleths show that the centre of the basin did not subside. On the sections of drainage area density isopleth, however, the centre of the basin appears to be strongly downfaulted. The reason is that the rivers at the downfaulted centre are few, causing low value of drainage length density, but they are wide, causing high value of drainage area density. It is therefore necessary to compare the two kinds of drainage density isopleths to determine true active features.

\section{Conclusions}

A method is described to interpret vertical movement of buried neotectonic features by analysis of drainage length density and drainage area density isopleths.

The method has been tested in the Weihe Basin. The basin, located in an extensional region in northwestern China, is tilted from north to south, but three subsiding centres has migrated slightly to the west. Structural movement is very strong along the south margin and has induced many geological hazards including intense earthquakes.

In this study the interpretation of the morphometric maps was supplemented by the use of Quaternary isopaches, geophysical data, geodetic survey, and by field checking. The results indicate that the morphometric analysis is valid. The morphometric method may be useful in a preliminary assessment of active tectonics in other buried 
basins, using only topographic maps, in areas where other sources of information are lacking. This should also be valuable in assessing areas with frequent geological hazards.

\section{Acknowledgements}

We are extremely grateful to A. G. Liu, B. Y. Li, S. M. Wang and J. Zhao, students of the Department of Geology, Peking University, Beijing, China for their assistance in the field work and data collection for topographic maps and to the State Education Commission of China for the Fund for Excellent Young University Teachers of the State Education Commission of China.

\section{REFERENCES}

Deng, Q. D. and You, H. C. 1985. The structural activity and formation mechanism of the down-faulted basins around Ordos block. Research on Recent Crustal Movement (1), Seismological Press, Beijing, China, 5878.

Han, H. Y. and Yi, X. F. 1982. The Cenozoic Weihe graben-basin and Huaxian great earthquake. in The Active Faults in China, Seismological Press, Beijing, China, 133-140.

Hou, J. J, 1985. The seismic and geological conditions of the earthquake in Huaxian, Shanxi province ( $M=8.0$, Jan. 23,1556$)$. Nothwestern Seismological Journal, 7(1): 66-74.

Hou, J. J. 1991. Geometrical method to determine the detachment depth of tilt block. Seismology and Geology, 13(4): 377-383.

Hou, J. J., Bai, T. X., Liang, H. H., Zheng, W. T. and Wang, S. M. 1995. Active features of the hangingwall on the listric normal fault along the southeastern margin of Weihe basin. Earthquake Research in China, 9(3): 305-310.

Hou, J. J., Han M. K. Bai, T. X. et al., 1994. Active fault zone along northern Huashan piedmont and geological hazard in Shanxi province. Journal of China University of Geosciences, 5(1): 37-40.

Moretti, I., Colletta B and Vially R 1988. Theoretical model of block rotation along circular faults. Tectonophysics, (153): 313-320.

Pan, J. X., Wu, Y. B. and Zhang, Y. X. 1993. Discussion on earthquakes in Huaxian, Shanxi province and in Yueyang, Hunan province in 1556. Seismology and Geology, (15)3: 261-267.

Shentu, B. M., Song, F. M. and Cao, Z. Q.1991. Preliminary study on late Quaternary fault scarps on the northern piedmont of Qinling mountain. Seismology and Geology, (13)1: 15-25.

Su, S. R. 1991. Drainage system and its implications of the modern tectonic movement in Weihe basin. Journal of Xi'an College of Geology, (13)1: 23-29.

Wang, J. M. 1983. Active tectonics and earthquakes in Weihe basin. Crustal Deformation and Earthquake, (3)4: 59-66.

Wang, J. M. 1989. Ground fissure in the city of Xi' an. Seismology and Geology, (11)3: 85-93.

Wang, X. W. 1987. Characteristics of vertical deformation in the central Weihe basin. Crustal Deformation and Earthquake, (7)2: 98-102.

Xie, Z. Q.,Fang, J. A. and TianX. T. 1991. The evolution of the structural stress field and analysis of the formation mechanism in the Weihe basin. Journal of Xi' an College of Geology, (13) 1: 46-52.

Zhang, A. L., Mi, F. S, and Zhong, J 1989. Deformation relics of the 1556 Huaxian great earthquake and the study of palaeoseismicity on the frontal fault zone of the Huanshan Mt.. Seismology and Geology, (11)3: 73-81.
Hou Jianjun was born in 1955 and was educated at Peking University where he completed both his undergraduate and doctoral degrees in active tectonics. Since 1982, he has worked in the Department of Geology. Peking University as a teacher and gained the title of associate professor in 1992, and further studied in the University of California at Berkeley, U, S. A. from 1987 to 1988 .

Han Mukang is Professor of the Department of Geography, Peking University, Beijing. Since the 1970s. he has studied the relations between seismotectonics and tectonic geomorphology in several strong earthquake regions in China,. His other interests involve application of GIS to morphotectonic mapping, and analysis of impacts of sea level rise.

Cliff D. Ollier is an Emeritus Professor in the Department of Geography and Planning, University of New England, Armidale, Australia. Now he is working as a consultant in the Center for Resources and Environmental Studies, Australia National University. His research has been on geomorphology, weathering, land classification, tectonics and landscape evolution.
